\title{
ANALISA KUANTITATIF CAMPURAN SENYAWA OKSIDA SEBAGAI DASAR IDENTIFIKASI KANDUNGAN BAHAN SUMBER DAYA ALAM \\ Studi Kasus : Kandungan Mineral pada Pasir Besi di Pesisir Pantai Selatan, Jawa Barat
}

\author{
Setianto $^{1 *}$, Budy Santosa ${ }^{2}$, Darmawan Hidayat ${ }^{3}$ and Camellia Panatarani ${ }^{1}$ \\ ${ }^{1}$ Jurusan Fisika, FMIPA, Universitas Padjadjaran Bandung, Indonesia \\ ${ }^{2}$ Jurusan Geofisika, FMIPA, Universitas Padjadjaran Bandung, Indonesia \\ ${ }^{3}$ Jurusan Teknik Elektro, FMIPA, Universitas Padjadjaran Bandung, Indonesia Jalan Raya \\ Bandung-Sumedang KM 21, Sumedang 45363, Indonesia \\ setianto@phys.unpad.ac.id
}

\begin{abstract}
ABSTRAK
Pasir besi merupakan salah satu sumber daya alam yang melimpah di Indonesia terutama di pantai selatan Jawa Barat dan merupakan bahan dasar untuk bangunan serta industri logam.Kandungan mineral pasir besi tersebut umumnya adalah oksida logam seperti magnetit, hematit dan silika/kuarsa. Pada penelitian ini akan dilakukan analisa kuantitatif kandungan senyawa oksida logam $\left(\mathrm{Fe}_{2} \mathrm{O}_{3}, \mathrm{Fe}_{3} \mathrm{O}_{4}\right)$ dan kuarsa $\left(\mathrm{SiO}_{2}\right)$ sebagai identifikasi mineral bijih besi yang memiliki aspek ekonomis untuk industri logam.hasil analisa bahwa kandungan magnetite yang terdapat pada pasir besi secara kuantitatif dengan menggunakan X-Ray Diffraction (XRD) berbeda untuk setiap sampel. Untuk sampel pasir nonseparasi (TS) menghasilkan magnetite 24.27\%, sampel tailing separasi ke-1 (SS1) menghasilkan magnetite 5.39\% dan sampel consentrate separasi ke-3 (S3) menghasilkan 61.98\%
\end{abstract}

Kata Kunci : magnetite, hematite, Rietveld refinement

\section{PENDAHULUAN}

Pasir besi merupakan salah satu sumber daya alam yang melimpah di Indonesia terutama di pantai selatan Jawa Barat dan merupakan bahan dasar untuk bangunan serta industri logam. Kandungan mineral pasir besi tersebut umumnya adalah oksida logam seperti besi, timah dan silika/kuarsa. Salah satu bahan dasar yang dibuat menggunakan pasir besi adalah kandungan magnetit $\left(\mathrm{Fe}_{3} \mathrm{O}_{4}\right)$ yang digunakan sebagai bahan dalam pembuatan logam besi. Terlepas dari carut marutnya konflik pasir besi di Indonesia, memang harus ada sikap tegas dari Pemerintah dan penegak hukum. Dinas Pertambangan daerah akan ompong tanpa adanya tindakan dari aparat kepada penambang-penambang liar, namun akan lebih tak bergigi lagi jika pemerintah sebagai pembuat regulasi tidak memberikan sanksi sebesar-besarnya kepada pada penambang liar tersebut. Hal ini bukan untuk melarang kegiatan penambangan pasir besi, namun harus mengatur supaya semua pihak yang 
E-ISSN : 2549-7464, P-ISSN : 1411-3724

terlibat dan masyarakat tidak terkena dampak dari aktivitas penambangan. Reklamasi di bekas lahan penambangan bisa dilakukan[1,2,3,4,5], yaitu dengan menambahkan bahan-bahan organik pada lokasi bekas tambang.Pada pasir yang berwarna hitam, mineral yang mendominasi adalah magnetit $\left(\mathrm{Fe}_{3} \mathrm{O}_{4}\right)$, hematit $\left(\mathrm{Fe}_{2} \mathrm{O}_{3}\right)$,

Limonit $\left(\mathrm{Fe}_{2} \mathrm{O}_{3} \cdot \mathrm{nH}_{2} \mathrm{O}\right)$, Siderit

$\left(\mathrm{FeCO}_{3}\right)$. Semakin gelap warna dari pasir, menunjukkan konsentrasi unsur Fe yang makin tinggi [Andi Yahya, 2014].Pasir besi umumnya terdiri dari mineral opak yang bercampur dengan butiran-butiran dari mineral non logam seperti, kuarsa $\left(\mathrm{SiO}_{2}\right)$, kalsit, feldspar, ampibol, piroksen, biotit, dan tourmalin. Mineral bijih pasir besi terutama berasal dari batuan basaltik dan andesitik vulkanik[6,7].

\section{METODE PENELITIAN}

Secara umum, untuk proses preparasi sampel, pasir besi dari hasil tambang di pantai selatan Jawa Barat diambil dalam porsi yang bervariasi sesuai dengan lokasi yang ada. Masing-masing sampel yang berupa serbuk/butiran tersebut diayak dengan menggunakan ayakan berukuran 60mesh sampai dengan 200mesh. Pengayakan sangat luas dipakai untuk pemisahan ukuran $300 \mathrm{~mm}$ hingga menjadi ukuran sekitar $40 \mathrm{~m}$, meskipun efisiensi ikut menurun seiring dengan tingkat kehalusan[8,9,10]. Ayakan kering biasanya terbatas pada material di atas 5 $\mathrm{mm}$, sedangkan ayakan basah umumnya berukuran $250 \mathrm{~m}$, metode untuk penanganan material di bawah $250 \mathrm{~m}$ ditangani dengan menggunakan metode klasifikasi.Kemudian menentukan distribusi partikel pasir besiyang dihasilkan dengan sebuah software komersial.Sampel hasil ayakan kemudian dikeringkan pada suhu $100^{\circ} \mathrm{C}$ yang bertujuan untuk menghilangkan kadar air. Kemudian dilakukan pengukuran SEM dan XRD untuk mengetahui morfologi dan struktur kristal dari sampel pasir besi tersebut.

\section{HASILPENELITIAN DAN PEMBAHASAN}

\section{a. Analisis Pola Intensitas untuk Sampel Pasir Nonseparasi (TS)}

Pola intensitas terhadap 2 tetha yang didapatkan dai hasil uji XRD untuk sampel tanpa proses separator (XRD) diperlihatkan pada gambar 1 .

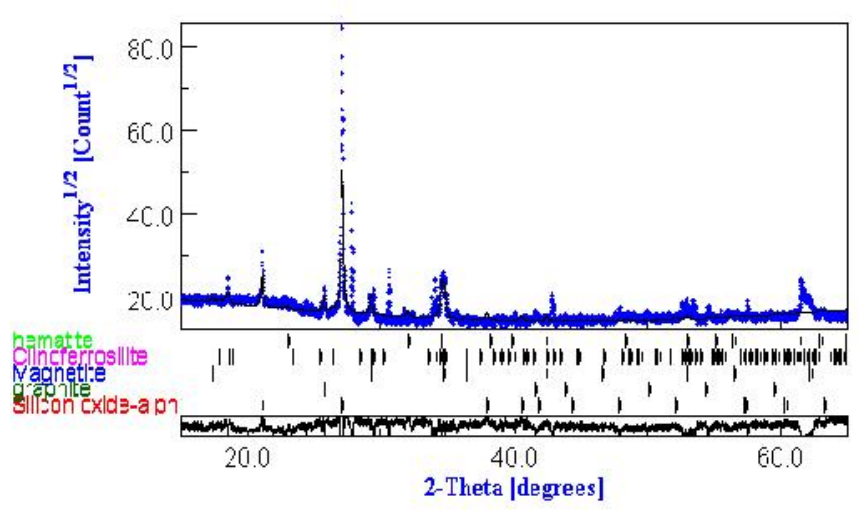

Gambar 1 Pola intensitas untuk sampel TS

Gambar 1 merupakan pola intensitas hasil analisis menggunakan software MAUD. Grafik pola di atas merupakan grafik intensitas ${ }^{1 / 2}$ terhadap 2 tetha. Pada gambar 1, puncak intensitas tertinggi terdapat pada posisi 2 tetha $27^{\circ}$ dengan intensitas mencapai 7000 dan tepat berada pada database silicon oxide-alpha. Dapat dipastikan mineral paling banyak yang dikandung oleh sampel TS adalah silicon oxide-alpha. Untuk graphite puncak intensitas berada pada posisi 2 tetha sekitar $25,5^{\circ}$ dengan intensitas mencapai 625. Untuk magnetite, clinoferrosilite dan hematite terjadi interferensi konstruktif dengan puncak intensitas berada pada 


\section{Eksakta Vol. 18 No. 2 Oktober $\mid 2017$}

E-ISSN : 2549-7464, P-ISSN : 1411-3724

posisi 2 tetha sekitar $35^{\circ}$ dengan intensitas mencapai 841.

Adapun hasil kuantitatif yang dihasilkan dari sampel TS dapat dilihat pada tabel 2 berikut:

Tabel 1. Hasil kuantitatif sampel TS

\begin{tabular}{|l|l|l|}
\hline Mineral & $\begin{array}{l}\text { Kuantitatif } \\
(\%)\end{array}$ & $\begin{array}{l}\text { Error } \\
(\%)\end{array}$ \\
\hline $\begin{array}{l}\text { Magnetite } \\
\left(\mathrm{Fe}_{3} \mathrm{O}_{4}\right)\end{array}$ & 24,27 & 0,85 \\
\hline $\begin{array}{l}\text { Hematite } \\
\left(\mathrm{Fe}_{2} \mathrm{O}_{3}\right)\end{array}$ & 0,89 & 0,16 \\
\hline $\begin{array}{l}\text { Silicon oxide- } \\
\text { alpha }\left(\mathrm{SiO}_{2}\right)\end{array}$ & 61,77 & 0,00 \\
\hline Graphite $(\mathrm{C})$ & 8,34 & 0,87 \\
\hline $\left.\begin{array}{l}\text { Clinoferrosilite } \\
\text { (FeSiO }\end{array}\right)$ & 4,73 & 0,49 \\
\hline
\end{tabular}

Hasil dari tabel 1 diatas terbukti bahwa mineral yang terkandung dalam sampel TS yang paling tinggi adalah silicon oxide-alpha sebesar $61,77 \%$ dengan error sebesar 0\%. Sesuai dengan yang terlihat pada pola grafik bahwa pada sampel TS, intensitas yang paling tinggi berada pada 2 tetha $27^{\circ}$ dengan besar intensitas berkisar 7000. Kandungan paling tinggi kedua adalah magnetite sebesar 24,27\% dengan error sebesar $0,85 \%$. kandungan paling tinggi ke tiga adalah graphite sebesar $8,34 \%$ dengan error sebesar $0,87 \%$. Selanjutnya ada clinoferrosilite sebesar $4,73 \%$ dengan error sebesar 0,49. Dan yang paling sedikit adalah hematite sebesar 0,89\% dengan error sebesar 0,16\%.

\section{b. Analisis Pola Intensitas untuk Sampel Consentrate Separasi ke-3 (S3)}

Pola intensitas terhadap 2 tetha yang didapatkan dari hasil uji XRD untuk sampel pasir S3 diperlihatkan pada gambar 2 berikut :

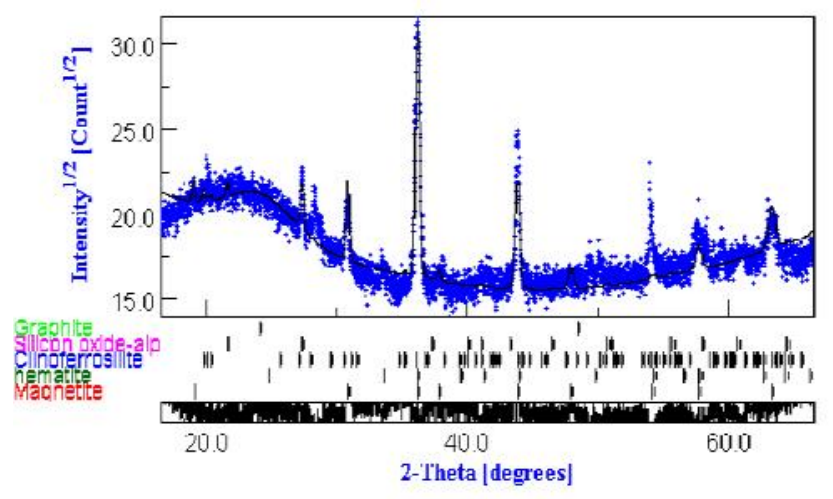

Gambar 2 Pola intensitas untuk sampel S3

Pada gambar 2. pola intensitas untuk sampel S3 diatas terlihat bahwa puncak intensitas tertinggi terdapat pada posisi 2 tetha $35^{\circ}$ dengan intensitas mencapai 1000. Puncak intensitas tertinggi merupakan hasil dari interferensi konstruktif dari magnetite, hematite, dan clinoferrosilite. Adapun hasil kuantitatif yang dihasilkan dari sampel TS dapat dilihat pada tabel 2. berikut:

Tabel 2 Hasil kuantitatif sampel S3

\begin{tabular}{|c|c|c|}
\hline Mineral & $\begin{array}{l}\text { Kuantitatif } \\
(\%)\end{array}$ & $\begin{array}{l}\text { Error } \\
(\%)\end{array}$ \\
\hline Magnetite $\left(\mathrm{Fe}_{3} \mathrm{O}_{4}\right)$ & 61,98 & 0,00 \\
\hline Hematite $\left(\mathrm{Fe}_{2} \mathrm{O}_{3}\right)$ & 0,07 & 0,30 \\
\hline $\begin{array}{l}\text { Silicon oxide- } \\
\text { alpha }\left(\mathrm{SiO}_{2}\right)\end{array}$ & 4,92 & 3,75 \\
\hline Graphite (C) & 30,03 & 1,16 \\
\hline $\begin{array}{l}\text { Clinoferrosilite } \\
\left(\mathrm{FeSiO}_{3}\right)\end{array}$ & 3,00 & 0,65 \\
\hline
\end{tabular}

Hasil dari tabel 2 diatas bahwa mineral yang terkandung dalam sampel S3 yang paling tinggi adalah magnetite sebesar $61,98 \%$ dengan error sebesar $0 \%$. 
Kandungan paling tinggi kedua adalah graphite sebesar $30,03 \%$ dengan error sebesar $1,16 \%$. kandungan paling tinggi ke tiga adalah silicon oxide-alpha sebesar 4,92\% dengan error sebesar $3,75 \%$. Selanjutnya ada clinoferrosilite sebesar 3,00\% dengan errorsebesar $0,65 \%$. dan yang paling sedikit adalah Hematite $\left(\mathrm{Fe}_{2} \mathrm{O}_{3}\right)$ sebesar $0,07 \%$ dengan error sebesar $0,30 \%$. Bila membandingkan hasil kuantitatif magnetite sampel S3 lebih besar jika dibandingkan dengan sampel TS. Besarnya nilai kuantitatif untuk sampel S3 menunjukkan hasil separasi dengan magnetik separator yang sesuai. Magnetik separator yang digunakan berhasil menseparasi pengotor yang terkandung di dalam pasir, sehingga kandungan magnetite menjadi lebih banyak. Hasil kuantitatif untuk hematite sampel S3 lebih kecil jika dibandingkan dengan sampel TS. Kecilnya hasil kuantitatif untuk sampel S3 ini, terjadi karena hematite merupakan magnetik lemah sehingga saat proses separasi terjadi hematite akan jatuh karna gaya gravitasi. Sifat hematite yang merupakan magnetik lemah yang gaya magnetnya tidak cukup besar untuk menempel pada drum separator. Hasil kuantitatif untuk graphite sampel S3 lebih besar jika dibandingkan dengan sampel TS. Hal ini menunjukkan saat proses separasi, graphite banyak yang ikut menempel pada drum separator. Hasil kuantitatif untuk clinoferrosilite sampel S3 lebih sedikit dibandingkan dengan sampel TS dan SS1. Hal ini menunukkan bahwa hasil separator dengan menggunakan magnetik separator dapat mengurangi clinoferrosilite. Hasil kuantitatif untuk silicon oxide-alpha sampel S3 lebih sedikit dibandingkan dengan sampel TS. Hal ini menunjukkan bahwa proses separasi dengan menggunakan separator magnetik dapat mengurangi silicon oxide-alpha pada pasir.

\section{KESIMPULAN}

a. Massa pasir yang dihasilkan dari hasil separasi terlihat semakin banyak separasi yang dilakukan maka, massa pasir yang terpakai (mengandung mineral magnetik) semakin berkurang. Sedangkan untuk pasir yang terbuang (tidak mengandung mineral magnetik) terlihat hasil yang fluktuatif. Hal tersebut terlihat bahwa hasil dari separasi dengan menggunakan alat magnetik separator ini, dari setiap separasinya selalu ada mineral magnetik yang ikut terbuang. Nilai recovery untuk massa umpan $2 \mathrm{~kg}$ adalah adalah 228,5624\% dan untuk massa umpan $0,020 \mathrm{~kg}$ adalah $69,4625 \%$. Nilai recovery tersebut menunjukkan alat magnetic separator yang digunakan tidak efektif untuk digunakan dalam skala besar.

b. Berdasarkan dari hasil analisa bahwa kandungan magnetite yang terdapat pada pasir besi secara kuantitatif dengan menggunakan X-Ray Diffraction (XRD) berbeda untuk setiap sampel. Untuk sampel pasir nonseparasi (TS) menghasilkan magnetite $24.27 \%$ dengan error 0.85 $\%$. dan sampel consentrate separasi ke-3 (S3) menghasilkan $61.98 \%$ dengan error 0 .

\section{DAFTAR PUSTAKA}

[1] Avner \& Sidney H. 1982. "Introduction to Physical Metallurgy" Tokyo: McGraw-Hill International Book Company.

[2] B.D. Cullityand S.R. Stock, Elements of X-Ray Diffraction 


\section{Eksakta Vol. 18 No. 2 Oktober 2017}

E-ISSN : 2549-7464, P-ISSN : 1411-3724

Third Edition, Prentice Hall Upper Saddle River, NewJersey 07458, (2001)

[3] Candra Kurniawan, Jurnal Ilmu Pengetahuan dan Teknologi, TELAAH Volume 29, Mei2011

[4] Chisholm, Hugh, ed. (1911). "Silica". Encyclopcedia

Britannica (ed. 11th). Cambridge University Press

[5] Greenwood, Norman N.; Earnshaw, Alan (1997). Chemistry of the Elements (2nd ed.). ButterworthHeinemann. ISBN 0080379419

[6] G. S. Rohrer, Structure and bonding in crystalline materials,
Cambrige university press, Cambridge, UK, 2001

[7] J.E Greedon, (1994), Magnetic oxides in Encyclopedia of Inorganic chemistry Ed. R. Bruce King, John Wiley \& Sons ISBN 0-471-93620-0

[8] Rietveld, H.M. 1967. Acta Crystallogr. 22

[9] Sudaryo, Sutjipto, Seminar Nasional V SDM Teknologi Nuklir, Yogyakarta, 2009, hlm. 715-722

[10] Y. Waseda, E. Matsubara, K. Shinoda, X-ray crystallography, Springer-Verlag Berlin Heidelberg, 2011 